Energy and Sustainability VIII 145

\title{
COMMITMENT TO USE SUSTAINABLE ENERGY IN A WORST-CASE SCENARIO: SAN QUINTÍN AGRICULTURAL REGION OF BAJA CALIFORNIA, MEXICO
}

\author{
ISAAC AZUZ-ADEATH \& ROBERTO ARREOLA-SEVILLA \\ Center for Innovation and Design in Engineering (CEID), CETYS University, Mexico
}

\begin{abstract}
The agricultural region of San Quintín in the Mexican state of Baja California is a $10,000 \mathrm{~km}^{2}$ semi-arid coastal plain located $300 \mathrm{~km}$ south of the US-Mexico border. It is one of the most important agricultural areas of the country thanks to the use of high technology and to the quality of its products. The San Quintín region is the main national exporter of berries, and $20 \%$ of the tomato exported to the USA is produced there. Economic development and social welfare options have been factors for population attraction (approximately 30,000 inhabitants in 2010, plus 5,000 temporal workers every year), which, in addition to the natural conditions of the area (no surficial rivers, $150 \mathrm{~mm} /$ year of rain), has led to critical hydrological stress (63\% of the aquifers are overexploited or salinized). Due to clean water scarcity and long-term drought, cultivated areas have been reduced from 25,000 ha in the 1980s to 8,000 in the present. Despite adverse conditions, San Quintín producers are committed to sustainability and are looking to be the first "green" agricultural district in the country by reducing their $\mathrm{CO} 2$ and hydrologic footprint during production. At least 67 desalination plants that process water from the aquifers operate in the region, and the first plant that will desalinize seawater for agricultural use is in process. Even with a government subsidy of $90 \%$ of the cost of energy used in the field, producers are considering the use of alternative energy for their desalination plants. This paper shows the strategies and cost of implementation of a renewable energy network for use in desalination plants in the agricultural region of San Quintín.

Keywords: sustainable energy, desalination plants, agricultural production, San Quintín, Mexico.
\end{abstract}

\section{INTRODUCTION}

The border region of California (USA) and Baja California (Mexico) is one of the most dynamic economic areas in the world. During the second quarter of 2018, Baja California experienced an economic growth of 3.6\%, thus becoming the state with the highest growth rate of the northern border of Mexico. In the same period, the primary economic activities in which agriculture is included, registered an increase of 9.8\% [1].

The San Quintín Valley is located $300 \mathrm{~km}$ south of the US-Mexico border and is part of the irrigation district of Ensenada. It is the largest agricultural valley in the state of Baja California, which is a state that functions with local water sources. With an approximate area of $10,000 \mathrm{~km}^{2}$ and a semi-arid climate, this area sits on the coastal plain of the Pacific littoral.

The most important agricultural crops of the San Quintín Valley are: tomatoes, strawberries, berries, grapes, cucumber and chili. This valley produces $20 \%$ of the Mexican tomatoes that are exported to the US market and is the main Mexican exporter of berries. The agricultural activities of the region, in addition to contributing to the state economy, employ thousands of workers and have contributed decisively to improving the living conditions of its inhabitants.

Despite the marked decrease in cultivable areas, the economic value of production shows a continuous increasing trend, as shown in Fig. 1. 

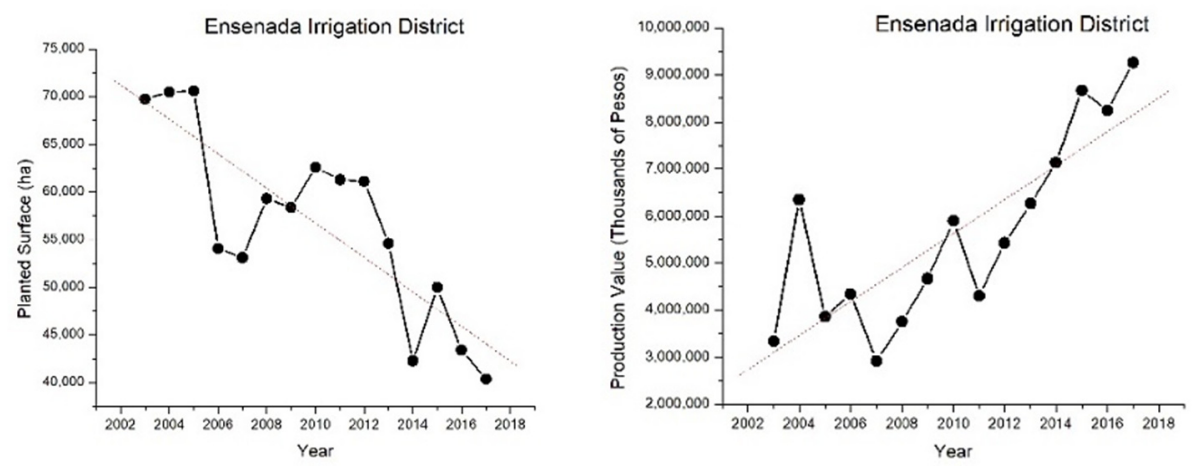

Figure 1: Historic planted surface (left) and production value (right) in the Ensenada irrigation district [2].

The cause of decreased cultivation areas is water scarcity in the region, which is due to lack of rainfall, surface rivers and a decrease of aquifer levels, as well as salinization of aquifers. Production value increases according to market conditions, quality of the products, intensive cultivation and use of agricultural technology (e.g. water efficiency strategies, extensive use of fertilizers and agrochemicals, better agricultural system management, etc.). Combined with lack of water, global warming has caused a considerable increase of atmospheric temperature [3]. Fig. 2 shows the behavior of some climatic variables (i.e. rain, maximum and minimum temperature) in the state of Baja California.

The San Quintín Valley has an annual average rainfall of $200 \mathrm{~mm}$ and there are no permanent rivers. Furthermore, out of the eight aquifers, three are overexploited, and three are salinized. In this scenario, the only option available to obtain water for agricultural purposes is the use of desalination plants. In 2017, at least 67 desalination plants are operating and registered at CONAGUA, the national water authority, and all of them use water from the salinized aquifers because they are cheaper to process than seawater due to their lower content of salt. It is difficult knowing the total water extraction capacity of the region because desalination plants are private, and are installed, operated and maintained by ranches and farms themselves. However, at least one of them has a capacity to process $24 \mathrm{l} / \mathrm{s}$. For comparative purposes, the El Paso water plant, which is the world's largest inland desalination facility, can produce up to 122 million liters per day [5], while in the San Quintín Valley, there is only one plant that produces 2 million liters per day.

The exact amount of energy needed to operate the desalination plants in San Quintín valley is unknown, but demand for electric power must be very large. All facilities are connected to the regional power grid (operated by the federal government through Comision Federal de Electricidad, or the Federal Electricity Commission), because the federal government subsidizes more than $90 \%$ of the cost of energy used for agricultural purposes. The Special Energy Program for Agricultural Use establishes that "if the regular cost of energy is 7.24 pesos per Kwh, and the farmer signs the agreement, the daytime cost will be 0.62 pesos per $\mathrm{kWh}$ and the nighttime cost will be 0.31 pesos per $\mathrm{kWh}$ ".

The state of Baja California has great potential for harnessing renewable energies in Mexico. In San Quintín Valley, the solar and wind potential was deemed high by the Ministry of Energy. The potential of solar energy ranges from 5500 to $5749 \mathrm{Wh} / \mathrm{m}^{2} /$ day, and wind velocity ranges from 6 to $7.25 \mathrm{~m} / \mathrm{s}$, with plant or power factor of 20 to $30 \%$, ideal for the 

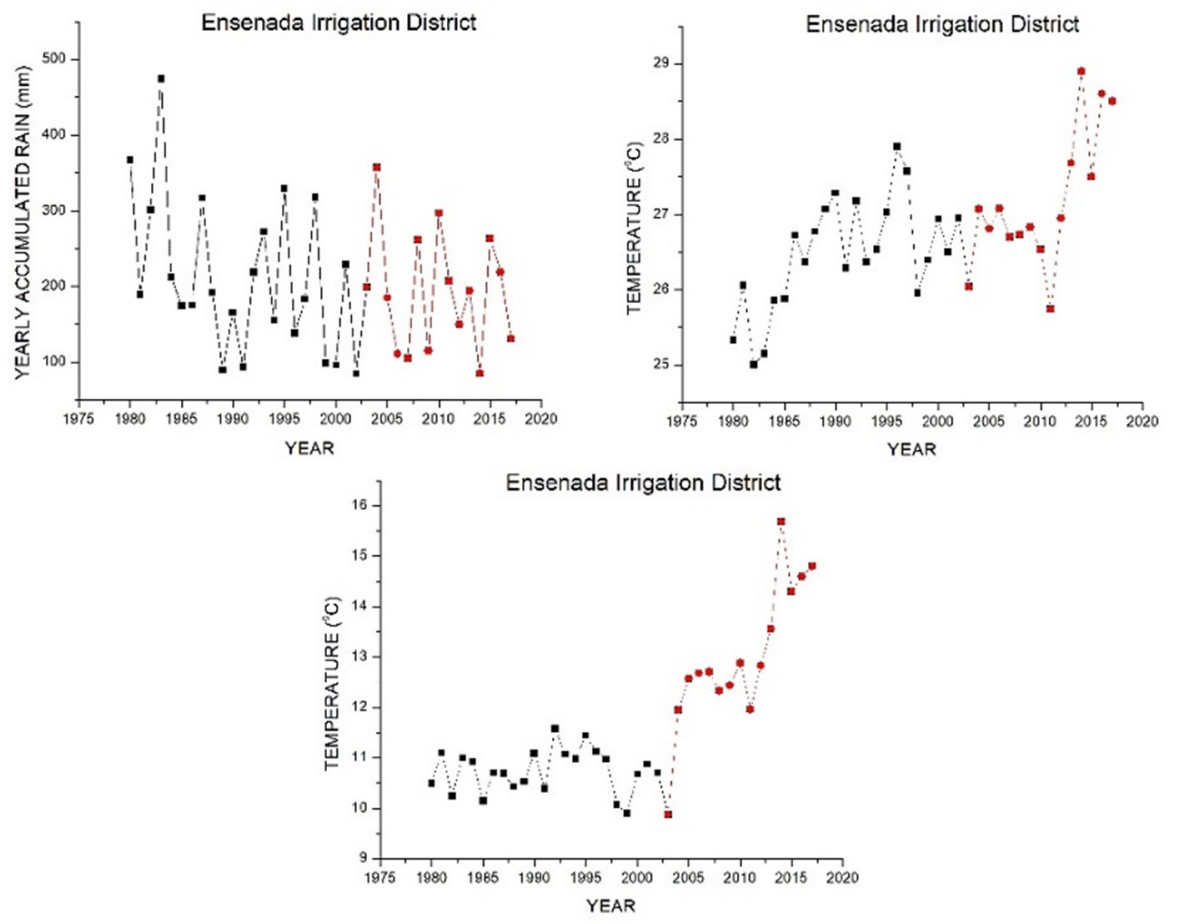

Figure 2: Historic accumulated rain (top left), maximum temperature (top right) and minimum temperature (bottom). The portion of the time series corresponding to the data period shown in Fig. 1 is marked in red [4].

installation of wind farms [6]. The coastline of this region (from Punta Colonet to El Rosario) is approximately $135 \mathrm{~km}$ long and has direct access to the Pacific Ocean. Even without having quantified wave power energy locally, it can be considered high, and it can be a potential source of electric power generation. Moreover, waste and debris from agricultural processes could be used as biofuel, since it is generated in large quantities during harvest.

It is a complex scenario: an agricultural region focused on exporting products with high added value, limited by the availability of water but that has implemented desalination at an industrial level, uses electric power from the grid thanks to large government subsidy, and is rich in natural conditions that give it unique qualities for exploitation of renewable energy sources. The only way to achieve sustainable development is if producers commit to develop a plan to gradually incorporate clean energy. Agricultural producers are aware of the problems that could arise from the introduction of tariff barriers or dumping policies to their product exports due to government subsidies and have decided to become the first "green" or sustainable agricultural district in Mexico. This paper shows the strategies and cost of implementation of a renewable energy network to be used in desalinization plants already installed in the agricultural region of San Quintin, Baja California, Mexico.

\section{STUDY AREA AND METHODOLOGY}

The San Quintín Valley is located in north western Mexico (see Fig. 3), in the state of Baja California, inside the Ensenada Municipality. Administratively, it comprises four 
delegations: Camalú, Vicente Guerrero, San Quintín and El Rosario, with a total surface of $10,311 \mathrm{~km}^{2}$. In 2010, the total permanent population of the San Quintín Valley was 26,557 inhabitants (roughly $10 \%$ of the county's population), but the fluctuating population associated with agricultural harvesting processes can represent up to $50 \%$ of the permanent population [7]. Many of these temporary workers decide to stay and live in the region, thus increasing the need for basic services and infrastructure, particularly water and energy. The main agricultural products produced in the region are: tomatoes, strawberries, berries, grapes, cucumbers, and chilies; most of them are produced for exportation.

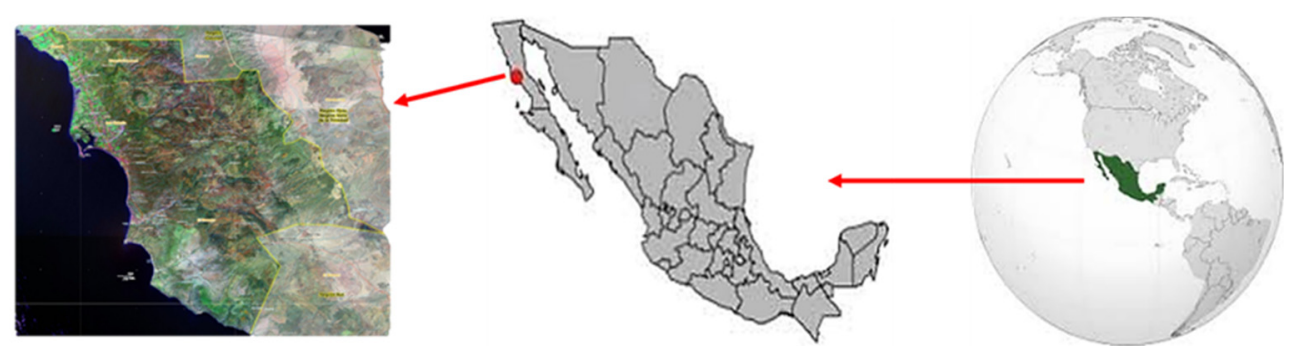

Figure 3: Study area, San Quintín region in Mexico. (Maps Sources: IMIP, 2018; INEGI, 2018 and Addicted04, MEX orthographic, CC BY-SA 3.0. [8], [9].)

In order to define the energy and hydric requirements of the San Quintín Valley, this study uses the two main crops in the area as a reference (tomatoes and strawberries). These crops represent approximately $63 \%$ of the planted surface in the valley and $64 \%$ of the total production value. Both products are cultivated under controlled conditions (i.e. high-tech greenhouses with water efficiency systems) in areas of 0.75 ha (1 greenhouse facility).

Without specific information about the type, operation conditions and capacity of all desalination plants in the region, this study is based on field information and personal communications with farmers, and uses the following assumptions: (i) all of the desalination plants use reverse osmosis, (ii) the smallest capacity plants produce $0.37 \mathrm{l} / \mathrm{s}$, (iii) the largest capacity plants produce $24 \mathrm{l} / \mathrm{s}$, (iv) based on information of three medium size desalination plants the energy efficiency was between $63 \%$ to $67 \%$ and, (v) the average monthly energy consumption for the desalination plant was obtained using one year of measured data $(\mathrm{kWh})$ from two medium size plants. The cost of energy for the desalination process also uses three scenarios: regular cost, diurnal energy cost with subsidy and nocturnal energy cost with subsidy.

To define the specific water needs for each type of crop, this study follows the methodology proposed by Fuentes-Yagüe and García-Legaspi [10], which is widely used in Mexico. This methodology considers the duration of the different growth stages of each crop, the type of soil, the local monthly mean surface atmospheric temperature, and plant and crop evapotranspiration quantities. The local values for some of the aforementioned variables were obtained from the Camalú station [11], the governmental measurement station closest to the study area. The crop coefficients (Kc) used in this study are shown in Table 1.

Total water required was calculated considering the water needs and planted area of both crops. Using this information and the scenarios proposed in the previous paragraphs regarding types of desalination plants and energy cost, the current total energy needs for the desalination plants used for agriculture in the San Quintín Valley were stablished. 
Table 1: Single (time-average) crop coefficients (Kc) used in this study [12].

\begin{tabular}{|c|c|c|c|c|}
\hline \multirow{2}{*}{ Crop stages } & \multicolumn{2}{|c|}{ Tomatoes } & \multicolumn{2}{c|}{ Strawberries } \\
\cline { 2 - 5 } & $\begin{array}{c}\text { Duration } \\
\text { (days) }\end{array}$ & $\mathrm{Kc}$ & $\begin{array}{c}\text { Duration } \\
\text { (days) }\end{array}$ & $\mathrm{Kc}$ \\
\hline 1 & 35 & 0.60 & 20 & 0.40 \\
\hline 2 & 40 & 1.15 & 50 & 0.85 \\
\hline 3 & 50 & 0.80 & 75 & 0.75 \\
\hline 4 & 30 & 0.60 & 60 & 0.20 \\
\hline Total & 155 & & 205 & \\
\hline
\end{tabular}

Different scenarios regarding the move towards use of renewable energy sources (solar photovoltaic and wind) were established considering the water and energy needs of the valley, including the time needed to achieve economic equilibrium.

\section{RESULTS: HYDROLOGICAL AND ENERGY NEEDS OF THE REGION}

The six main agricultural products of the San Quintín Valley represent less than $20 \%$ of the total planted surface in the irrigation district of Ensenada. However, in 2017 their production value accounts for $76 \%$ of the total income. Due to water availability restrictions, from 2003 to 2017 , the planted surface in the San Quintín Valley experienced a decrease of 30\%, going from roughly nine thousand hectares to seven thousand. Despite this, the value of production tripled, especially in the case of strawberry crops (see Table 2).

Table 2: San Quintín Valley main crops information 2003-2017 [13].

\begin{tabular}{|l|c|c|c|c|c|c|}
\hline \multirow{2}{*}{ Crop } & \multicolumn{3}{|c|}{ Year 2003 } & \multicolumn{3}{c|}{ Year 2017 } \\
\cline { 2 - 7 } & $\begin{array}{c}\text { Planted } \\
\text { Surface } \\
\text { (ha) }\end{array}$ & $\begin{array}{c}\text { Production } \\
\text { (ton) }\end{array}$ & $\begin{array}{c}\text { Production } \\
\text { value } \\
\text { (thousands } \\
\text { of Pesos) }\end{array}$ & $\begin{array}{c}\text { Planted } \\
\text { surface } \\
\text { (ha) }\end{array}$ & $\begin{array}{c}\text { Production } \\
\text { (ton) }\end{array}$ & $\begin{array}{c}\text { Production } \\
\text { value } \\
\text { (thousands } \\
\text { of Pesos) }\end{array}$ \\
\hline Chili & 684.0 & $14,269.4$ & $62,406.7$ & 815.0 & $22,516.4$ & $247,626.0$ \\
\hline Raspberry & 25.0 & 205.0 & $5,798.4$ & 829.0 & $12,048.5$ & $1,469,405.8$ \\
\hline Strawberry & 764.0 & $33,941.1$ & $324,979.2$ & $1,869.0$ & $91,660.3$ & $2,050,893.3$ \\
\hline Cucumber & $1,523.5$ & $48,546.2$ & $283,073.4$ & 712.6 & $54,979.1$ & $718,293.2$ \\
\hline Tomato & $5,608.2$ & $250,446.6$ & $1,575,898.9$ & $2,310.5$ & $179,005.7$ & $2,419,473.4$ \\
\hline Grape & 577.0 & $1,249.5$ & $6,473.1$ & 450.7 & $3,385.7$ & $34,085.0$ \\
\hline Blackberry & 2.0 & - & - & 56.0 & 721.5 & $76,951.5$ \\
\hline Total & $9,183.7$ & $348,657.8$ & $2,258,629.8$ & $7,042.8$ & $364,317.2$ & $7,016,728.2$ \\
\hline
\end{tabular}

Four stages of plant growth, as well as corresponding evapotranspiration (Evapo) were considered in order to calculate water needs for the two selected crops. This data provided the information necessary to establish the water needs of each cultivated hectare. Table 3 shows the results obtained from tomato crops.

Results show that one hectare of tomato crops requires, from sowing to harvest, $565.72 \mathrm{~mm}$ of total water, which represents 5,657 cubic meters or 5.6 million liters. Similar calculations were done for strawberry crops, resulting in a total of $3,352 \mathrm{~m}^{3}$ per hectare. 
Table 3: Example of water needs calculations for tomato crops.

\begin{tabular}{|c|c|c|c|c|}
\hline $\begin{array}{c}\text { Crop } \\
\text { stage }\end{array}$ & Date & $\begin{array}{c}\text { Time duration } \\
(\text { days })\end{array}$ & $\begin{array}{c}\text { Crop evapo } \\
(\mathrm{mm})\end{array}$ & $\begin{array}{c}\text { Monthly water } \\
\text { needs (mm) }\end{array}$ \\
\hline \multirow{2}{*}{1} & 1-30 April & 30 & 2.74 & 82.08 \\
\cline { 2 - 5 } & 1-5 May & 5 & 2.83 & \multirow{2}{*}{154.96} \\
\hline \multirow{2}{*}{2} & 5-31 May & 26 & 5.42 & \multirow{2}{*}{135.25} \\
\cline { 2 - 5 } & 1-14 June & 14 & 5.38 & 104.16 \\
\hline \multirow{3}{*}{3} & 15-30 June & 16 & 3.74 & 84.09 \\
\cline { 2 - 5 } & 1-31 July & 31 & 3.36 & 5.18 \\
\cline { 2 - 5 } & 1-3 August & 3 & 3.50 & 565.72 \\
\hline \multirow{2}{*}{4} & 4-31 August & 28 & 2.63 & \multicolumn{2}{|c}{} \\
\cline { 2 - 5 } & 1-2 September & 2 & 2.59 & \\
\hline \multirow{2}{*}{ Total } & & 155 & & \multicolumn{2}{|c}{} \\
\hline
\end{tabular}

Considering the total area occupied by both crops (tomatoes and strawberries) in the San Quintín Valley, the total amount of water required would be $5,657 \mathrm{~m}^{3} \times 2,310.5$ ha $+3,352.5$ $\mathrm{m}^{3} \times 1,869 \mathrm{ha}=19.3$ million cubic meters per agricultural cycle.

This amount of water must be obtained through desalination, which requires a large amount of energy. There is no single desalination plant that supplies the entire area; instead, there is a large number of plants in the area that are connected to the power grid, which in turn increase the operating costs because they form a dispersed distribution network. During this study we found 67 registered desalination plants with different capacities, all of them using the reverse osmosis method. Many farmers in the area consider the information related to water desalination and energy cost to be a confidential matter, however, the data related to an average or "type" plant was obtained for this study. This study uses the following data to make generalizations of the entire agricultural production area of the San Quintín Valley. Changes in desalination plant efficiency could modify these calculations:

- $\quad$ Water treated $(1 / \mathrm{h})=4,051$

- $\quad$ Water produced $(\mathrm{l} / \mathrm{h})=1,326$

- Water rejected $(\mathrm{l} / \mathrm{h})=2,725$

- $\quad$ Desalinization efficiency $=33 \%$

- Initial water quality/salinity $(\mathrm{ppm})=18,000$

- $\quad$ Final water quality/salinity $(\mathrm{ppm})=1.9$

- Average monthly energy consumption $(\mathrm{kWh})=6,840$

In the case of tomato crops (see Table 3), the total cultivation cycle lasts 155 days, which corresponds to approximately 5.2 months, and requires 13,070.5 million liters of water (total cultivation time times total cultivated area); for strawberry crop the cultivation cycle lasts 6.8 months, and require 6,262.8 million liters of total water. If only one desalination plant supplies the entire region, it should produce 2,500 million liters per month. Using the above information to calculate the energy consumption of a "type" desalination plant, roughly 1 million liters/month require $6.3 \mathrm{~kW}$ of energy, so the cultivated area corresponding to tomato crops in the San Quintin Valley would need (2,514 million 1/month) x (5.2 months) x (6.3 $\mathrm{kW} /$ million 1$)=82,359 \mathrm{~kW}$ or $82.4 \mathrm{MW}$ of energy for irrigation. Similar calculations were done for strawberry crops need (921 million $1 /$ month x 6.8 months x $6.3 \mathrm{~kW} /$ million 1 ), resulting in $39.5 \mathrm{MW}$ of energy consumption needed for irrigation. Therefore, the total 
energy demand to supply desalinate water for the two crops analyzed in the study region during one agricultural cycle would be $121.9 \mathrm{MW}$.

In Mexico there are different elements involved in the calculations of electric energy cost:

1. Geography. The country is divided into 8 regions according to income of the population. Different prices exist for each region.

2. Seasonality. The year is divided into summer and winter seasons. Different prices exist for each season.

3. Type of use and amounts used. Four different uses are defined with several categories each, according to the amount of energy used in each one: (a) residential, (b) public services, (c) agricultural irrigation and (d) general purposes. Different prices exist for each type of use and amount of energy used.

Considering the "type" conditions, the amount of Mexican pesos paid for each kWh of energy in the agricultural sector (without a governmental subsidy) is $\$ 7.24$ Mexican pesos. Considering this, the total amount of money required to pay for the energy needed to desalinate water for one agricultural cycle of tomato and strawberry crops in San Quintin, would be 636 million Mexican pesos (approximately 35.3 million American dollars). With the government subsidy (Special Energy Program for Agricultural Use) the total cost goes down to between 27.2 and 54.4 million Mexican pesos (considering the different costs for diurnal and nocturnal energy) or 1.5 to 3.0 million American dollars.

The potential of wind and solar energy in San Quintin region is very high [6], the agricultural region is located near the coastline (between 1 and $10 \mathrm{~km}$ ) directly in front of the open ocean (Pacific Ocean), and it has available enough land for the installation of large energy facilities (wind turbines, solar systems, etc.).

To meet the energy demand associated with desalination process for the crops analyzed in this study (approximately $122 \mathrm{MW}$ per agricultural cycle), only two general scenarios were considered: exclusive use of photovoltaic solar energy and exclusive use of terrestrial and marine wind energy. In the first case, considering solar panels with generation capacity of $250 \mathrm{~W}$ (common capacity of existing solar panels in the Mexican market), 488,000 solar panels would be needed. In the second scenario, using operational information from wind turbines in Europe [14] (in average 5,600 $\mathrm{kW}$ per marine turbine), the number of wind turbines required to supply the energy demand in the agricultural region, goes from 22 (marine) to 44 (terrestrial).

\section{CONCLUSIONS}

This study confirms the premise that "water availability and growth are interconnected" [15]. For the San Quintin region, the only option available to exist as a successful agricultural area is desalination. The two crops analyzed in this study require nearly 20 million cubic meters of water per agricultural cycle, which are obtained through desalination. The calculations show that regardless of the commitment made by farmers to obtain energy from renewable sources, the cost of this transition will be very high.

The water-energy-food nexus has emerged as a useful concept to describe and address the complex and interrelated nature of the global resource system, on which humans depend to achieve different social, economic and environmental goals [16]. In the present study, these links are evident and compromise the viability of the entire region.

The alternative visualized by the authors of this document implies a close collaboration between producers and the government. First of all, a gradual transition to the use of renewable energies is proposed, followed by a combination of power generation sources based on a model such as the following: 
a) The agricultural producers must define, in a consensual manner, the percentage of energy that will be generated using renewable sources without disconnecting from the traditional power grid.

b) Individually, farmers with low-capacity desalination plants should try to comply with the percentage established by means of photovoltaic cells.

c) Large agricultural producers should partner with the government to establish marine wind farms in the area. These projects must be implemented gradually until they meet the established percentages. The timeframe also needs to be defined in a consensual manner between producers and government.

d) All producers must collaborate with research centers and universities in the region to find more efficient and cheaper ways to generate renewable energy in the medium term.

\section{ACKNOWLEDGEMENTS}

This research was supported by the Center for Innovation and Design in Engineering (CEID) of the Engineering College of CETYS University. The authors appreciate all its support. Also, the authors acknowledge the comments made by Dr. Josue López Leyva, Dean of the Renewable Energy Department of CETYS Ensenada Campus, to the initial manuscript.

\section{REFERENCES}

[1] Indicador Trimestral de la Actividad Económica Estatal. Instituto Nacional de Estadística y Geografía. Online. http://www.beta.inegi.org.mx/temas/itaee/. Accessed on: 22 Jan. 2019.

[2] Servicio de Información Agroalimentaria y Pesquera. Secretaría de Agricultura y Desarrollo Rural. www.gob.mx/siap. Accessed on: 19 Oct. 2018.

[3] Azuz-Adeath, I., González-Campos, C. \& Cuevas-Corona, A., Predicting the temporal structure of the Atlantic Multidecadal Oscillation (AMO) for agriculture management in Mexico's coastal zone. Journal of Coastal Research, 35(1), pp. 210-226, 2019.

[4] Resúmenes mensuales de temperaturas y lluvias. Servicio Meteorológico Nacional. https://smn.cna.gob.mx/es/climatologia/temperaturas-y-lluvias/resumenesmensuales-de-temperaturas-y-lluvias. Accessed on: 16 Sep. 2018.

[5] Kay Bailey Hutchinson WTP. El Paso Water. www.epwater.org/cms/one.aspx? portalId $=6843488 \&$ pageId=7422402. Accessed on: 22 Nov. 2018.

[6] Atlas Nacional de Zonas con Alto Potencial de Energías Limpias, Secretaría de Energía. https://dgel.energia.gob.mx/AZEL/. Accessed on: 4 Jun. 2018.

[7] Índice de Marginación por Localidad 2010, Consejo Nacional de Población. www.conapo.gob.mx/en/CONAPO/Indice_de_Marginacion_por_Localidad_2010. Accessed on: 19 Aug. 2018.

[8] Catálogo de SIG y Mapas en Línea, Instituto Municipal de Investigación y Planeación del Municipio de Ensenada. http://imipens.org/catalogo-sig-en-linea/. Accessed on: 23 Sep. 2018.

[9] Imágenes del Territorio. Instituto Nacional de Estadística y Geografía. www.inegi.org.mx/datos/?t=0130000000000000. Accessed on: 23 Sep. 2018.

[10] Fuentes-Yagüe, J.L. \& García-Legaspi, G., Técnicas de riego. Sistemas de riego en agricultura. Grupo Mundi-Prensa: México, D.F., pp. 39-63, 1999.

[11] Estación Camalú, B.C., Variables Climáticas. Instituto Nacional de Investigaciones Forestales, Agrícolas y Pecuarias. http://clima.inifap.gob.mx/lnmysr/Estaciones/ ConsultaDiarios15Min?Estado=2\&Estacion=998421. Accessed on: 25 Jul. 2018. 
[12] Allen, R.G., Pereira, L.S., Raes, D. \& Smith, M., Crop Evapotranspiration Guidelines for Computing Crop Water Requirements, FAO Irrigation and drainage paper 56, Rome, 1998. www.fao.org/3/X0490E/X0490E00.htm.

[13] Información por Cultivo Distrito de Ensenada, B.C. Sistema de Información Agroalimentaria de Consulta. www.gob.mx/siap/documentos/siacon-ng-161430. Accessed on: 8 Sep. 2018.

[14] The European Offshore Wind Industry. Key Trends and Statistics 1st half of 2018, Wind Europe: Brussels, pp. 1-14, 2018.

[15] Lundqvist, J., 2014 Stockholm Water Prize laureate's presentation: The power of water by Professor John Briscoe. Aquatic Procedia, 5, pp. 3-7, 2015.

[16] Endo, A., Tsurita, I., Burnett, K. \& Orencio, P.M., A review of the current state of research on the water, energy, and food nexus. Journal of Hydrology: Regional Studies, 11, pp. 20-30, 2017. 